\title{
CAREER MANAGEMENT PROGRAMMES FOR ACADEMICS IN THE HIGHER EDUCATION SECTOR: A RE-AIM SYSTEMATIC REVIEW
}

\author{
N. Barnes* \\ Department of Industrial Psychology \\ Faculty of Economic and Management Sciences \\ https://orcid.org/0000-0002-5514-1201
}

\section{Du Plessis*}

Department of Industrial Psychology

Faculty of Economic and Management Sciences

https://orcid.org/0000-0002-3865-6959

\section{J. Frantz*}

Department of Physiotherapy

DVC Research and Innovation

https://orcid.org/0000-0002-8296-5601

*University of the Western Cape

Bellville, South Africa

\section{ABSTRACT}

Academic career development is a fundamental strategy for higher education institutions to achieve strategic objectives and in turn, critical for the achievement and sustainability of national priorities. While the value of a career management strategy is agreed and various normative designs for career management systems have been identified, there is no comprehensive career management approach to provide a framework for the successful management of academic careers across the various career stages. The aim of this study was therefore to systematically review the empirical research recorded on academic career development programmes that could inform and support the development of a structured career management framework for academics. A systems thinking framework (STF), which identifies the individual, social and socio-environment as the key systems, was used to categorise and thematically examine the sample articles which formed part of the study. While the STF recognises the individual as central to the career development process, the predominant programmes are constructed in the social system, with a clear focus on what institutions could do to support the career trajectory of academics. These programmes include coaching and mentoring for early career academics, together with the development of academic writing skills. Minimal research that explicitly describes the interaction and inseparability of these systems as a central construct of the STF is found. There is also no clear evidence of how the higher education context within the socio-environmental system is 
considered and captured during the management of academic careers. This article concludes by identifying critical considerations for the development of an academic career management framework.

Keywords: academic career development, career management, career development programmes, systems thinking framework (STF), higher education sector, RE-AIM

\section{INTRODUCTION}

A failure to invest in the development and progression of academic careers, as a focused and differentiated strategy, has far-reaching consequences and implications for South African higher education institutions and moreover, for the development and sustainability of national priorities. The necessity for this investment is underpinned by global trends of massification, globalisation and internationalisation, together with national transformation requirements, which in turn, place considerable demands on the higher education system. The Council on Higher Education (CHE) review in 2016 acknowledges these demands and more particularly, the effect on the academic profession $(2016,304)$. The demands on the academic profession and change in the academic role appear to be a dominant theme in academic career literature (Theron, Barkhuizen, and Du Plessis 2014, 1). At the same time these growing pressures in the higher education system result in discouraging environments for the academic profession and the subsequent view that the meanings associated with becoming or being an academic is contested and constantly changing (Pithouse-Morgan et al. 2016, 225).

With this demanding and challenging context in mind, the 2016 CHE review further identifies key concerns relating to the filling and increase of the academic pipeline. Research on the attraction and retention of academic staff supports the concern that the capacity and sustainability of South African higher education institutions are threatened by the exodus of academics (Callaghan 2015, 3). It is within this demanding and challenging context, that the value of a systematic career development approach for academics is evident.

Szelągowska-Rudzka $(2017,210)$ suggests that the success of a university, just like any other organisation, depends primarily on the employees, their competence, commitment and motivation to perform the mission, goals and tasks of the university. Furthermore, the researcher argues, that the career development and satisfaction of academics influence the results achieved by the university, the level of educational services provided and the quality of scientific research. Theron, Barkhuizen, and Du Plessis $(2014,11)$ advocated that higher education institutions are more dependent on the commitment and intellectual capital of their knowledge workers, than any other organisation. These authors further state, that the responsibility of higher education institutions to contribute to the sustained development of South Africa is 
dependent on the career development of valued and talented academics $(2014,12)$. This is supported by the 2016 CHE review that highlighted that academic career development is timely and important, as a fundamental requirement to unlock South Africa's potential as a research destination $(2016,208)$.

The value of a career management strategy is agreed and various normative designs for career management systems have been recognised by many scholars (Baruch and Peiperl 2000; De Vos and Cambré 2017). However, a recent review confirms that there is no comprehensive career management approach to provide a framework for the successful management of academic careers across various career stages (Zacher et al. 2019, 357). In support of this review, the researchers argue that working in academia is a unique career path in comparison to other professions. Individual abilities and motivations, working conditions, governance and institutional structures, policy approaches, and thus, career development practices in academic contexts differ substantially from other sectors and industries (Baruch 2013). Therefore, it is important to conduct a review on career management programmes for academics that can inform a theoretical and evidence-based framework for the successful management of academic careers.

The overarching aim of this systematic review was to identify the empirical research recorded on academic career development programmes that could inform and support the development of a comprehensive career management framework for academics. The review was guided by the following research question: What types of academic career development programmes exist in the higher education sector? The objectives of the study were therefore to:

1. Systematically review and establish the literature concerning the particular types of career development programmes for academics; and

2. Discuss the types of programmes as outlined by a systems thinking framework that could inform the development of a comprehensive career management framework for academics.

\section{THEORETICAL FRAMEWORK}

The theoretical framework of this systematic review is underpinned by a systems thinking framework (STF), which is described by Young and Popadiuk (2012) as a metatheoretical perspective that has made strong contributions to the career development field, especially to the interconnections between theory, research and practice. The purpose of utilising the STF is twofold, as according to Blustein (2014), it is an excellent framework within which to locate 
and utilise the extant theoretical insights of career development. It also demonstrates the influences relevant to an individual's career development, showing the many complex and interrelated systems within which, such development occurs (McMahon and Patton 2018).

The systems theory approach recognises the individual as central to the STF, based on a number of theoretical perspectives (Parsons 1909; Super 1990). As a system in its own right, the individual holds a range of intrapersonal influences on the career development process, such as personality, ability, interest, self-concept and gender (Patton and McMahon 2014). However, the STF acknowledges that the individual system does not function in isolation, but rather as part of a broader contextual system. The framework divides this broader contextual system into two subsystems, including the social system and the environmental-societal system (Patton and McMahon 2014).

The social system includes the principle social influences with which individuals interact and receive input. These principle social influences include structures such as the workplace, peers and the family. Patton and McMahon (1999) highlight that the composition of these social influences' changes throughout life. It will thus be essential to consider the social system of a particular individual and the exact nature of the system within which that individual coexists during the career development process $(1999,250)$. The second contextual sub-system, which is the environmental-societal system, represents the broader society or environment in which the individual lives, including the employment market, historical trends, globalisation, politics and the socio-economic context. According to Patton and McMahon (1999), the influences in the environmental-societal system may seem less directly related to the individual, yet their impact is profound on career development.

The STF acknowledges the process of influence both within and between these systems. Patton and McMahon (1999) use the term recursiveness to describe this process of influence, which refers to the interaction, the multi-directionality of influence, and the relationship between all systems, keeping in mind that the individual system and contextual subsystems are open systems and permeable to influence. Recursiveness is a central construct of the STF and emphasises the inseparability of parts from the whole and therefor it is essential to think of career development as an integrated and dynamic system (Vondracek, Ford, and Porfeli 2014).

With this theoretical framework in mind, it is important to note that career management is thus defined through an individual perspective and an organisational perspective (De Vos and Cambré 2017). This is demonstrated by the wide body of research that has addressed career management at the level of the individual employee (Abele and Wiese 2008; De Vos, De Clippeleer, and Dewilde 2009; De Vos and Soens 2008; Direnzo, Greenhaus, and Weer 2015; Eby, Butts, and Lockwood 2003; Greenhaus and Kossek 2014; Gubler, Arnold, and Coombs 
2014; King 2004; Strauss, Griffin, and Parker 2012), as well as career research that has focused on management strategies and practices within an organisational context (Baruch 2006; Clarke 2013; De Vos and Dries 2013; Dries, Van Acker, and Verbruggen 2012; Eby, Allen, and Brinley 2005; Lee, Felps, and Baruch 2014; Lips-Wiersma and Hall 2007; Segers and Inceoglu 2012)

Career management from an individual perspective is defined as a process by which individuals develop, implement and monitor their career goals and strategies (Greenhaus, Callanan, and Godshalk 2010), with a strong focus on the responsibility and benefits of the individuals to manage their own career (De Vos and Cambré 2017). From an organisational perspective, career management is concerned with the intervention, i.e., strategy and practices that plans and shapes the development and progression of employees in accordance with the organisation's talent management needs, which are to ensure that there is a talent flow that creates and maintains the required talent pool (Baruch and Peiperl 2000; Guan et al. 2015). For the purpose of this review, a systems thinking framework was used to establish and describe the empirical literature that provides insight into the management of academic careers from an individual and an organisational perspective.

\section{METHODOLOGY}

The study adopted the Reach, Effectiveness, Adoption, Implementation, and Maintenance (REAIM) framework to review and appraise the identified career development programmes as empirically captured.

\section{Search strategy}

The study included a comprehensive two-phased approach from August 2019 to November 2019. An initial scoping review was completed to identify similar systematic reviews conducted on the topic. An article by Zacher et al. (2019) that captures the review of academic career development literature, to gain understanding of the extent to which central constructs and processes through the lens of social cognitive career theory and life-span theory, was identified. However, the identified article did not address the research question of the current systematic review which is: What types of academic career development programmes exist in the higher education sector?

Several comprehensive literature searches were subsequently conducted. Electronic databases identified for the review include Scopus, Sabinet and Google Scholar, as guided by their relevance of content matter and accessibility of the researcher's university. The search strategy was based on the PIO (Population, Intervention, Outcome) assessment framework 
which is used in the development of literature search strategies (Schardt et al. 2007) and developed in consultation with a faculty librarian as an expert. The population included academics, the intervention included the types of programmes, with the outcome as the career development of academics. The keywords "academic career development, career management programmes, higher education and academic staff" were identified for the search, and together with The Boolean operators "AND" and "OR" entered in "All fields" as follows:

1. academic career development AND career management programmes AND higher education AND academic staff

2. academic career development OR academic career management

3. career management programmes AND higher education AND academic staff.

All English language peer-reviewed articles between 2009 and 2019 were included with no additional filters added.

\section{Study selection}

The selection of articles for this review had to meet certain criteria and these included (i) The target population of the studies had to include academic staff employed in the higher education sector who have participated in a career development programme. (ii) The career development programme identified as the intervention, should consider a process of activities with the intent to plan and shape the development and progression of the academics. Programmes are therefore not the isolated training, workshops or practices in a system, but aim to consider respective individual and institutional needs, while including some level of pre- and/or post-assessment or elements of monitoring and evaluation. (iii) Peer-reviewed studies conducted nationally and internationally within the last ten years were considered, while (iv) qualitative, quantitative and mixed methodologies were included. Systematic review articles were excluded from the search as this study takes a systematic review format.

The review included three levels of assessment, with title identification as the first level, abstract screening as the second level, and full-text review as the third level. During title identification, relevant titles of studies were identified based on the parameters of the review, while irrelevant titles were excluded, together with those that were not accessible through the university databases. Book chapters and conference papers were also not included. During abstract screening, reasons for exclusion included studies that focused on the academic development of undergraduate students; studies for the purpose of school counselling; as well 
as studies conducted in academic medical institutions with academic physicians as the sample population. The understanding is that the employment terms and context of academic physicians are different to traditional academics (Fairchild et al. 2004, 214). Full-text articles of the potential studies were then reviewed at a third level by utilising the RE-AIM critical appraisal tool for the purpose of the methodological quality assessment. Figure 1 outlines the three level assessment approach.

\section{Methodological quality assessment}

The RE-AIM critical appraisal tool includes five dimensions of quality assessment, namely: reach; effectiveness, adoption; implementation and maintenance. Each dimension includes further items to appraise the intervention while utilising a dichotomous scale of "yes" as 1 or "no" as 0 to inform a composite score that guides the methodological quality of the intervention. A quality appraisal threshold of 70 per cent was adopted by excluding all articles scoring less, while considered as either a poorly developed, executed, or reported intervention. The threelevel review was conducted by the researcher and an independent reviewer. Table 1 illustrates the methodological quality assessment.

\section{Data extraction}

The data extraction table was based on the work of Isaacs et al. (2018) and aligned with the STF as the theoretically unpinning of the study. The data extraction categories included (1) authors and year; (2) target population; (3) strategic intent and aim of programme; (4) programme development and needs analysis; (5) structure of the intervention in terms of 5.1) individual level, 5.2) social level, 5.3) environment-societal level, and 5.4) element of recursiveness; and (6) the outcome and impact of the programme. The results of the data extraction are described in Table 1.

\section{Data analysis}

A narrative synthesis was identified as the appropriate method to synthesise the data.

\section{Ethics}

Ethical clearance for the bigger study was granted by the University of the Western Cape, reference: HS19/6/41 which included conducting a systematic review. 

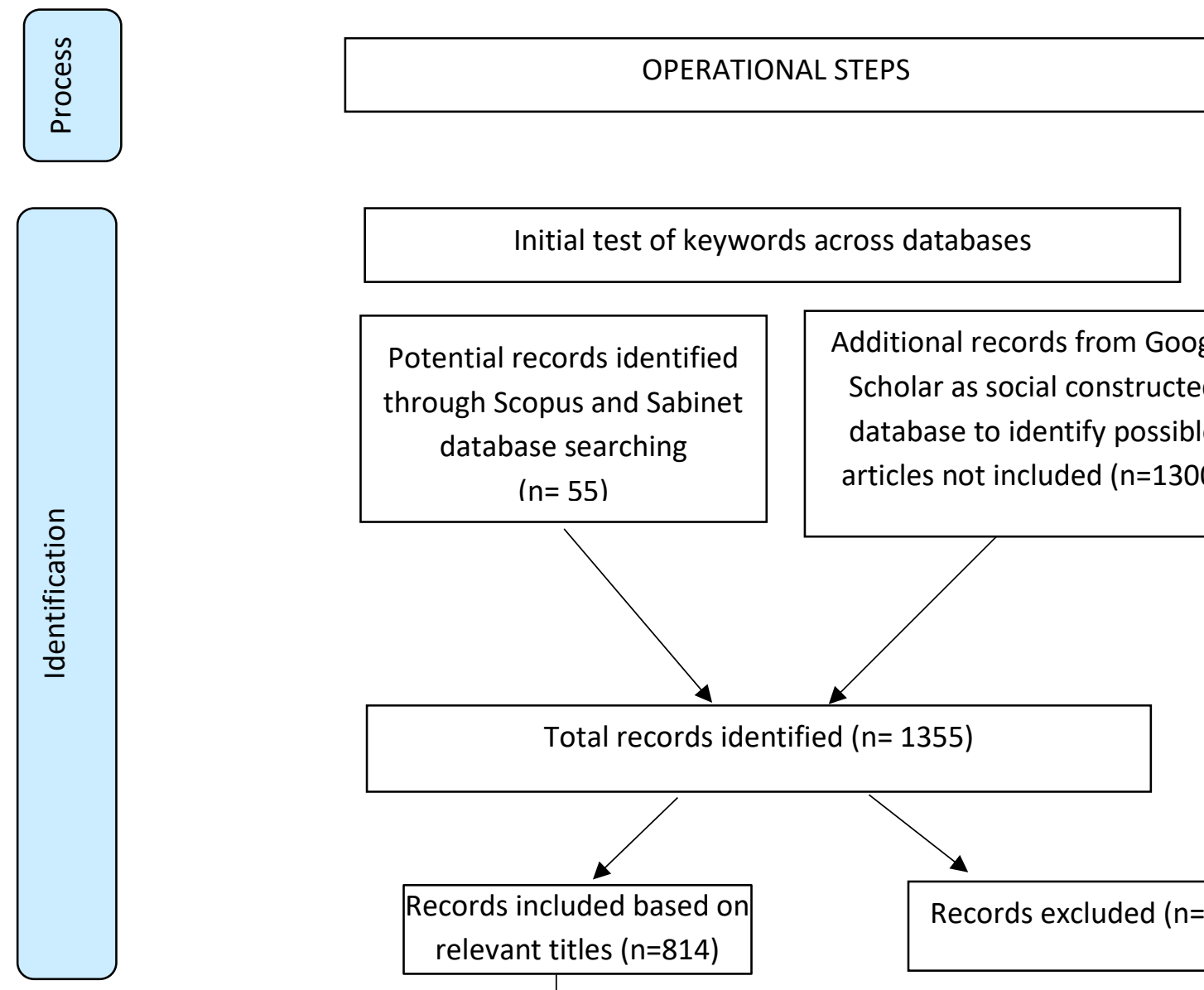

Additional records from Google Scholar as social constructed database to identify possible articles not included $(n=1300)$

Total records identified $(n=1355)$
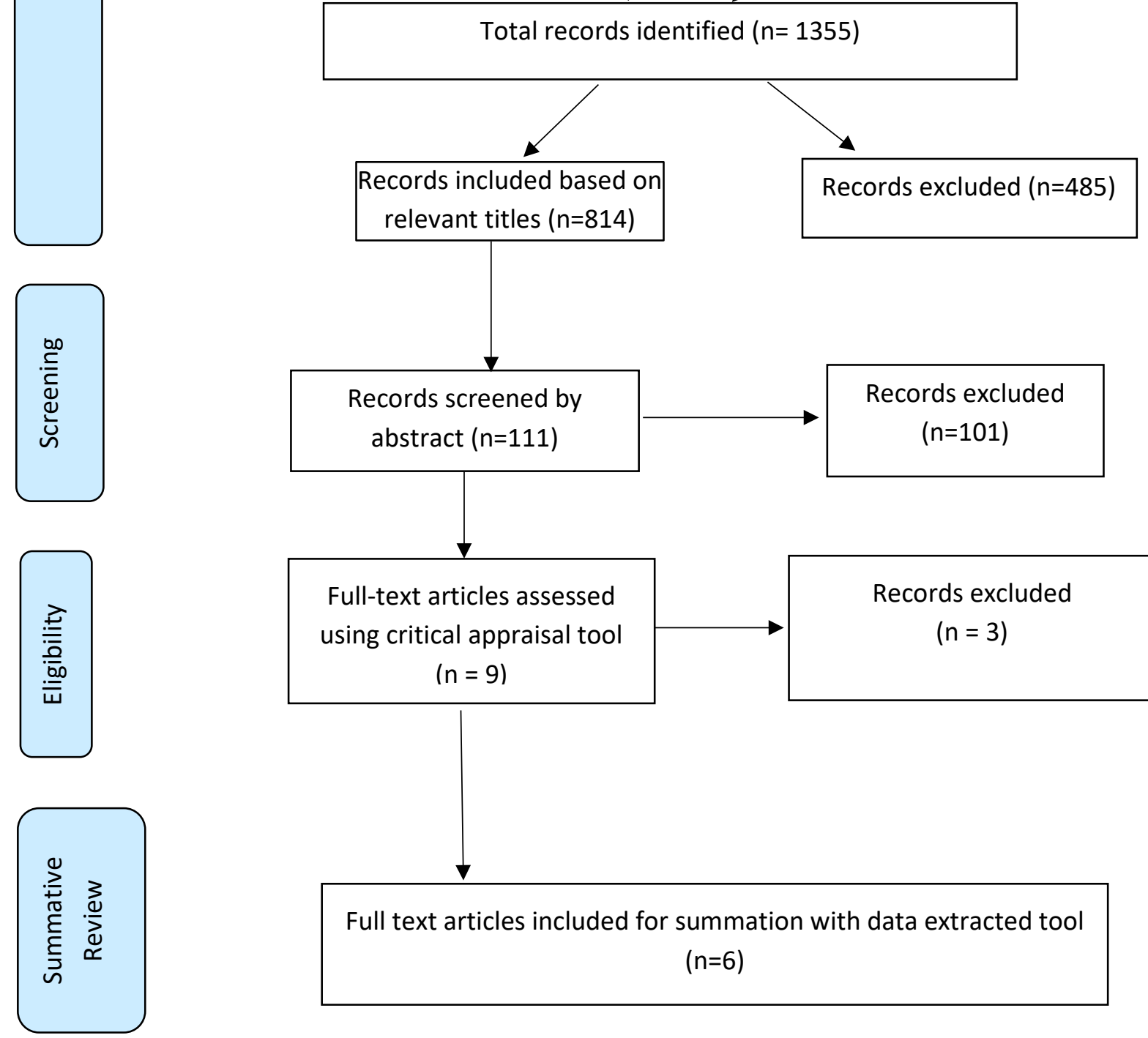

Figure 1: Process of Systematic Review (Adapted from Moher et al., 2015) 
Table 1: Data extraction

\begin{tabular}{|c|c|c|c|c|c|c|c|c|c|}
\hline \multirow[b]{2}{*}{$\begin{array}{c}\text { Author(s) and } \\
\text { Year }\end{array}$} & \multirow[b]{2}{*}{ Article } & \multirow{2}{*}{$\begin{array}{c}\text { Target } \\
\text { audience (and } \\
\text { location- } \\
\text { national/interna } \\
\text { tional) }\end{array}$} & \multirow[b]{2}{*}{$\begin{array}{l}\text { Strategic intent } \\
\text { and aim of } \\
\text { programme }\end{array}$} & \multirow[b]{2}{*}{$\begin{array}{l}\text { Programme } \\
\text { development - } \\
\text { needs analysis }\end{array}$} & \multicolumn{4}{|c|}{ Structure of intervention } & \multirow[b]{2}{*}{ Outcomes } \\
\hline & & & & & Individual & Social & $\begin{array}{l}\text { Environmenta } \\
\text { I-societal }\end{array}$ & $\begin{array}{l}\text { Recursive- } \\
\text { ness }\end{array}$ & \\
\hline 1. Geber (2009) & $\begin{array}{l}\text { "Research success } \\
\text { and structured } \\
\text { support: developing } \\
\text { early career } \\
\text { academics in higher } \\
\text { education." South } \\
\text { African journal of } \\
\text { higher education 23, } \\
\text { no. } 4 \text { (2009): 674- } \\
689 .\end{array}$ & $\begin{array}{l}\text { Early-career } \\
\text { academics } \\
\text { (SA) }\end{array}$ & $\begin{array}{l}\text { To increase } \\
\text { academics holding } \\
\text { PhDs and address } \\
\text { the challenge of } \\
\text { establishing a } \\
\text { publication record } \\
\text { in peer reviewed } \\
\text { and accredited } \\
\text { journals. }\end{array}$ & $\begin{array}{l}\text { Sound } \\
\text { theoretical base } \\
\text { - Literature } \\
\text { review aimed at } \\
\text { strategic intent. } \\
\text { Individual needs } \\
\text { assessment was } \\
\text { not included for } \\
\text { programme } \\
\text { design. }\end{array}$ & $\begin{array}{l}\text { Hard skills training } \\
\text { offered on } \\
\text { a) Core: Research } \\
\text { Writing; Voice and } \\
\text { Presentation; } \\
\text { Effective speed } \\
\text { reading; Time and } \\
\text { stress } \\
\text { management. } \\
\text { b) Optional - IT } \\
\text { tools }\end{array}$ & $\begin{array}{l}\text { Coaching with a } \\
\text { coach of choice } \\
-12 \text { sessions } \\
\text { over } 8 \text { months. } \\
\text { Part of core } \\
\text { course. }\end{array}$ & $\begin{array}{l}\text { Hard skills: } \\
\text { NRF proposal } \\
\text { writing } \\
\text { (although } \\
\text { individual skill } \\
\text { development, } \\
\text { it focuses on } \\
\text { env-soc level) }\end{array}$ & $\begin{array}{l}\text { Coaching } \\
\text { allowed } \\
\text { insights into } \\
\text { varies levels, } \\
\text { structures and } \\
\text { spaces, } \\
\text { including the } \\
\text { environmental- } \\
\text { societal level. } \\
\text { Instrumental in } \\
\text { alignment and } \\
\text { brining all } \\
\text { together. }\end{array}$ & $\begin{array}{l}\text { Tangible outcomes } \\
\text { are demonstrated } \\
\text { with an increase of } \\
\text { research output with } \\
\text { coaching identified } \\
\text { as a key } \\
\text { determinant for } \\
\text { programme } \\
\text { effectiveness. }\end{array}$ \\
\hline $\begin{array}{l}\text { 2. Benvenuti } \\
\text { (2017) }\end{array}$ & $\begin{array}{l}\text { "Pedagogy of } \\
\text { peers: Cultivating } \\
\text { writing retreats as } \\
\text { communities of } \\
\text { academic writing } \\
\text { practice." South } \\
\text { African Journal of } \\
\text { Higher } \\
\text { Education 31, no. } 2 \\
\text { (2017): 89-107. }\end{array}$ & $\begin{array}{l}\text { Academics at all } \\
\text { levels } \\
(\mathrm{SA})\end{array}$ & $\begin{array}{l}\text { Increase the } \\
\text { research } \\
\text { productivity of } \\
\text { academics at all } \\
\text { levels in a } \\
\text { research-intense } \\
\text { university. }\end{array}$ & $\begin{array}{l}\text { Literature review } \\
\text { - aligned and } \\
\text { adjusted to a } \\
\text { conceptual } \\
\text { framework. } \\
\text { Participants } \\
\text { were asked their } \\
\text { level of need, } \\
\text { which was used } \\
\text { to finalise } \\
\text { programme. } \\
\text { Programme } \\
\text { reviewed, } \\
\text { including } \\
\text { participant } \\
\text { feedback, after } \\
\text { first two for } \\
\text { refining. } \\
\end{array}$ & $\begin{array}{l}\text { Optional mini- } \\
\text { workshops to } \\
\text { develop individual } \\
\text { skill (agency/adult } \\
\text { learning - } \\
\text { understanding } \\
\text { own need and } \\
\text { navigating/control } \\
\text { learning) }\end{array}$ & $\begin{array}{l}\text { Platform - } \\
\text { space and time } \\
\text { created through } \\
\text { means of writing } \\
\text { retreat. COP - } \\
\text { Peer review } \\
\text { platforms } \\
\text { (artificially) } \\
\text { constructed. }\end{array}$ & $\begin{array}{l}\text { No explicit } \\
\text { element. }\end{array}$ & $\begin{array}{l}\text { Peer review } \\
\text { opportunities } \\
\text { created. }\end{array}$ & $\begin{array}{l}\text { An increase in } \\
\text { research output. }\end{array}$ \\
\hline $\begin{array}{l}\text { 3. Kapp, } \\
\text { Albertyn, and } \\
\text { Frick (2011) }\end{array}$ & $\begin{array}{l}\text { "Writing for } \\
\text { publication: An } \\
\text { intervention to } \\
\text { overcome barriers to } \\
\text { scholarly } \\
\text { writing." South } \\
\text { African Journal of } \\
\text { Higher }\end{array}$ & $\begin{array}{l}\text { Early career } \\
\text { academics - } \\
\text { novice and } \\
\text { advanced } \\
\text { beginners } \\
\text { (SA) }\end{array}$ & $\begin{array}{l}\text { Identify and } \\
\text { address barriers of } \\
\text { academic writing }\end{array}$ & $\begin{array}{l}\text { Theoretical } \\
\text { perspectives, } \\
\text { observations } \\
\text { and surveys } \\
\text { amongst target } \\
\text { population }\end{array}$ & $\begin{array}{l}\text { Individual } \\
\text { preparation as first } \\
\text { component of } \\
\text { structure. } \\
\text { Workshops } \\
\text { included individual } \\
\text { skill development, }\end{array}$ & $\begin{array}{l}\text { Platform for } \\
\text { writing in } \\
\text { supportive } \\
\text { environment, } \\
\text { with team of } \\
\text { specialists } \\
\text { providing } \\
\text { feedback. } \\
\end{array}$ & $\begin{array}{l}\text { No explicit } \\
\text { element. }\end{array}$ & $\begin{array}{l}\text { Action } \\
\text { Learning. One- } \\
\text { to-one } \\
\text { feedback by } \\
\text { peers and } \\
\text { experts during } \\
\text { the workshop. }\end{array}$ & $\begin{array}{l}\text { A framework in } \\
\text { support of writing for } \\
\text { publication. }\end{array}$ \\
\hline
\end{tabular}




\begin{tabular}{|c|c|c|c|c|c|c|c|c|c|}
\hline \multirow[b]{2}{*}{$\begin{array}{c}\text { Author(s) and } \\
\text { Year }\end{array}$} & \multirow[b]{2}{*}{ Article } & \multirow{2}{*}{$\begin{array}{c}\text { Target } \\
\text { audience (and } \\
\text { location- } \\
\text { national/interna } \\
\text { tional) }\end{array}$} & \multirow{2}{*}{$\begin{array}{l}\text { Strategic intent } \\
\text { and aim of } \\
\text { programme }\end{array}$} & \multirow{2}{*}{$\begin{array}{l}\text { Programme } \\
\text { development - } \\
\text { needs analysis }\end{array}$} & \multicolumn{4}{|c|}{ Structure of intervention } & \multirow[b]{2}{*}{ Outcomes } \\
\hline & & & & & Individual & Social & $\begin{array}{l}\text { Environmenta } \\
\text { I-societal }\end{array}$ & $\begin{array}{l}\text { Recursive- } \\
\text { ness }\end{array}$ & \\
\hline & $\begin{array}{l}\text { Education 25, no. } 4 \\
\text { (2011): 741-759. }\end{array}$ & & & & $\begin{array}{l}\text { together with } \\
\text { theoretical input. }\end{array}$ & & & & \\
\hline $\begin{array}{ll}\text { 4. } & \text { Ferguson and } \\
\text { Wheat (2015) }\end{array}$ & $\begin{array}{l}\text { "Early career } \\
\text { academic mentoring } \\
\text { using Twitter: the } \\
\text { case of\# } \\
\text { ECRchat." Journal } \\
\text { of higher education } \\
\text { policy and } \\
\text { management } 37, \text { no. } \\
1 \text { (2015): } 3-13 \text {. }\end{array}$ & $\begin{array}{l}\text { Early career } \\
\text { academics } \\
\text { (International/ } \\
\text { Global platform) }\end{array}$ & $\begin{array}{l}\text { Peer-mentoring: a } \\
\text { global cross- } \\
\text { disciplinary } \\
\text { discussion group. } \\
\text { To build on } \\
\text { established } \\
\text { practices and } \\
\text { compliment local } \\
\text { career } \\
\text { development } \\
\text { resources and } \\
\text { networks. }\end{array}$ & $\begin{array}{l}\text { Informal social } \\
\text { media initiative, } \\
\text { driven by } \\
\text { participants of } \\
\text { an early career } \\
\text { academic } \\
\text { community. }\end{array}$ & $\begin{array}{l}\text { Pro-active } \\
\text { approach of early } \\
\text { career academics } \\
\text { to address career } \\
\text { issues, identified } \\
\text { and driven by self. }\end{array}$ & $\begin{array}{l}\text { Social platform } \\
\text { used for peer- } \\
\text { mentoring forum } \\
\text { allows for } \\
\text { interaction with } \\
\text { peers. }\end{array}$ & $\begin{array}{l}\text { No explicit } \\
\text { element. }\end{array}$ & $\begin{array}{l}\text { Knowledge } \\
\text { sharing and } \\
\text { support } \\
\text { amongst } \\
\text { participants. }\end{array}$ & $\begin{array}{l}\text { Career } \\
\text { management } \\
\text { approach to } \\
\text { compliment and not } \\
\text { replace structured } \\
\text { workplace support, } \\
\text { created opportunity } \\
\text { for participants to } \\
\text { support and share } \\
\text { knowledge amongst } \\
\text { each other. }\end{array}$ \\
\hline $\begin{array}{l}\text { 5. Abodunde } \\
(2018)\end{array}$ & $\begin{array}{l}\text { "Mentoring and Its } \\
\text { Influence on Career } \\
\text { Development of } \\
\text { Academic Members } \\
\text { of Selected Tertiary } \\
\text { Institutions in Oyo } \\
\text { State, } \\
\text { Nigeria." Asian } \\
\text { Research Journal of } \\
\text { Arts \& Social } \\
\text { Sciences (2018): 1- } \\
9 .\end{array}$ & $\begin{array}{l}\text { Early career - } \\
\text { junior academic } \\
\text { members } \\
\text { (Africa) }\end{array}$ & $\begin{array}{l}\text { To raise academic } \\
\text { standards and } \\
\text { increase } \\
\text { institutional } \\
\text { performance. }\end{array}$ & $\begin{array}{l}\text { Literature and } \\
\text { empirical review. }\end{array}$ & $\begin{array}{l}\text { Programme } \\
\text { recognises the } \\
\text { need for personal } \\
\text { decision/conscious } \\
\text { effort of mentee to } \\
\text { be mentored and } \\
\text { allows them to } \\
\text { approach senior } \\
\text { colleagues with } \\
\text { their identified } \\
\text { development } \\
\text { problems. }\end{array}$ & $\begin{array}{l}\text { Creates } \\
\text { platforms } \\
\text { through the } \\
\text { provision of } \\
\text { academic } \\
\text { leadership by } \\
\text { senior } \\
\text { academics. }\end{array}$ & $\begin{array}{l}\text { No explicit } \\
\text { element. }\end{array}$ & $\begin{array}{l}\text { Mentoring } \\
\text { includes } \\
\text { mutual respect } \\
\text { and dependent } \\
\text { on the } \\
\text { appreciation of } \\
\text { the value by } \\
\text { both mentor } \\
\text { and mentee. }\end{array}$ & $\begin{array}{l}\text { Informal mentoring } \\
\text { has a significant } \\
\text { impact on the career } \\
\text { development of } \\
\text { academics. }\end{array}$ \\
\hline $\begin{array}{l}\text { 6. Undiyaundeye } \\
\text { and Basake } \\
\text { (2017) }\end{array}$ & $\begin{array}{l}\text { "Mentoring and } \\
\text { Career Development } \\
\text { of Academics in } \\
\text { Colleges of } \\
\text { Education in Cross } \\
\text { River State } \\
\text { Nigeria." European } \\
\text { Journal of } \\
\text { Multidisciplinary } \\
\text { Studies 2, no. } 4 \\
\text { (2017): 98-104. }\end{array}$ & $\begin{array}{l}\text { Early career - } \\
\text { young scholars } \\
\text { or less } \\
\text { experienced } \\
\text { (Africa) }\end{array}$ & $\begin{array}{l}\text { Career } \\
\text { development and } \\
\text { advancement of } \\
\text { early career } \\
\text { academics (young } \\
\text { scholars or less } \\
\text { experienced) for } \\
\text { institutional } \\
\text { effectiveness }\end{array}$ & $\begin{array}{l}\text { Literature } \\
\text { review. Makes } \\
\text { provision for } \\
\text { formal, informal } \\
\text { and group } \\
\text { mentoring. }\end{array}$ & $\begin{array}{l}\text { Informal mentoring } \\
\text { allows individual } \\
\text { agency in that the } \\
\text { newly employed } \\
\text { lecturer may seek } \\
\text { advice and } \\
\text { guidance from } \\
\text { experienced } \\
\text { lecturers. Mentees } \\
\text { are still allowed to } \\
\text { express their own } \\
\text { views. }\end{array}$ & $\begin{array}{l}\text { Formal and } \\
\text { group mentoring } \\
\text { allows for a } \\
\text { platform on } \\
\text { social level. }\end{array}$ & $\begin{array}{l}\text { No explicit } \\
\text { element. }\end{array}$ & $\begin{array}{l}\text { Mentoring is } \\
\text { based on a } \\
\text { developmental } \\
\text { social learning } \\
\text { perspective } \\
\text { which posits } \\
\text { that learning } \\
\text { happened } \\
\text { through } \\
\text { interaction with } \\
\text { others. }\end{array}$ & $\begin{array}{l}\text { Mentoring has a } \\
\text { significant effect on } \\
\text { the professional } \\
\text { growth of the } \\
\text { academia, while } \\
\text { recognising the } \\
\text { different challenges } \\
\text { experienced by } \\
\text { male and female } \\
\text { mentees. }\end{array}$ \\
\hline
\end{tabular}




\section{RESULTS}

Six articles were included for extraction and analysis after the eligibility of nine full-text articles were assessed by using the RE-AIM critical appraisal tool. The three articles that were excluded, all scored below the 70 per cent threshold. The methodological quality of the six articles included for the review, is illustrated in Table 2.

Table 2: Methodological quality assessment

\begin{tabular}{|c|c|c|c|c|c|c|}
\hline & $\begin{array}{l}\text { 1. Geber } \\
(2009)\end{array}$ & $\begin{array}{l}\text { 2. Benvenuti } \\
(2017)\end{array}$ & $\begin{array}{l}\text { 3. Kapp } \\
\text { et al. } \\
\text { (2011) }\end{array}$ & $\begin{array}{l}\text { 4. Ferguson } \\
\text { and Wheat } \\
(2015)\end{array}$ & $\begin{array}{l}\text { 5. Abodunde } \\
(2018)\end{array}$ & $\begin{array}{l}\text { 6. Undiyaundeye } \\
\text { and Basake } \\
(2017)\end{array}$ \\
\hline \multicolumn{7}{|l|}{ REACH } \\
\hline $\begin{array}{l}\text { 1: Indication of who the } \\
\text { programme is intended for }\end{array}$ & 1 & 1 & 1 & 1 & 1 & 1 \\
\hline 2: Participation rate & 1 & 1 & 1 & 1 & 1 & 1 \\
\hline \multicolumn{7}{|l|}{ EFFECTIVENESS } \\
\hline $\begin{array}{l}\text { 3: Model used for the } \\
\text { development of the } \\
\text { programme }\end{array}$ & 1 & 1 & 1 & 1 & 1 & 1 \\
\hline $\begin{array}{l}\text { 4: Did the programme achieve } \\
\text { intended objective }\end{array}$ & 1 & 1 & 1 & 1 & 1 & 1 \\
\hline 5: Limitations & & & & 1 & 1 & 1 \\
\hline 6: Outcome of intervention & 1 & 1 & 1 & 1 & 1 & 1 \\
\hline \multicolumn{7}{|l|}{ 7: Reports on attrition } \\
\hline \multicolumn{7}{|l|}{ ADOPTION } \\
\hline 8: Setting description & 1 & 1 & & 1 & 1 & 1 \\
\hline $\begin{array}{l}\text { 9: Reports on who delivered } \\
\text { the programme }\end{array}$ & 1 & 1 & 1 & 1 & 1 & 1 \\
\hline $\begin{array}{l}\text { 10: Did the participants report } \\
\text { on the programme }\end{array}$ & 1 & 1 & 1 & 1 & 1 & 1 \\
\hline \multicolumn{7}{|l|}{ IMPLEMENTATION } \\
\hline 11: Duration and frequency & 1 & 1 & 1 & 1 & & 1 \\
\hline $\begin{array}{l}\text { 12: Participant involvement in } \\
\text { the programme }\end{array}$ & 1 & 1 & 1 & 1 & 1 & 1 \\
\hline $\begin{array}{c}\text { 13: Reports on intended and } \\
\text { delivered interventions }\end{array}$ & 1 & 1 & 1 & 1 & 1 & 1 \\
\hline \multicolumn{7}{|l|}{ MAINTENANCE } \\
\hline $\begin{array}{l}\text { 14: Report on intervention } \\
\text { follow-up }\end{array}$ & 1 & & 1 & & & \\
\hline $\begin{array}{l}\text { 15: Long-term effects on the } \\
\text { intervention }\end{array}$ & & & 1 & & & \\
\hline
\end{tabular}

\section{Study characteristics}

Five of the six studies included for the review, were conducted in developing countries, including South Africa and Nigeria, with only one study that was jointly conducted in the developed countries of Australia and the United Kingdom.

\section{Findings}

A notable percentage of career development programmes in the higher education sector are 
found to be aimed at early career academics. Only one of the reviewed articles (Benvenuti 2017) included a programme that was targeted towards academics at all career levels.

While the strategic intent of all the reviewed articles clearly indicated that programmes are in support of the career development of academics, 50 per cent of the programme objectives aimed to develop the academic writing competency and in turn, increase research productivity of the respective institutions (Benvenuti 2017; Geber 2009; Kapp, Albertyn, and Frick 2011). The remainder of the programmes acknowledges a broader scope of the academic role and challenges such as networking (Ferguson and Wheat 2015), teaching and sharing of general resources and experiences (Abodunde 2018; Undiyaundeye and Basake 2017).

All the reviewed programmes are underpinned by sound theoretical and literature frameworks, while only two of the articles included individual needs assessments during the programme development phase (Benvenuti 2017; Kapp et al. 2011).

At the same time, the structure of the reviewed programmes in terms of the various STF levels show:

\section{Individual system}

All programmes included elements of individual development by either offering a set of skill development workshops for participants (Benvenuti 2017; Geber 2009) or customising individual support through a coaching or mentoring relationship (Kapp et al. 2011; Abodunde 2018). One of the programmes, categorised as a peer-mentoring programme, was initiated and coordinated by academics, who were also participants of the initiative (Ferguson and Wheat 2015). The individual development initiatives offered to participants included workshops on topics such as presentation skills, effective speed reading, time and stress management, information technology (Geber 2009), as well as research writing (Geber 2009; Benvenuti 2017).

\section{Social system}

The predominant focus of programmes appears to be recorded in the social system, with a clear indication of what universities do in support of academic career development. Coaching and mentoring are found to be central to all of the reviewed programmes, as extracted in Table 1, and included at minimum one of the methodologies, that were structured either formally (Geber 2009; Kapp et al. 2011), informally (Abodunde 2018), or peer driven (Ferguson and Wheat 2015). Another dominant focus of career management practices in the social system was revealed to be an opportunity for academic writing retreats or platforms (Benvenuti 2017; Kapp et al. 2011). 


\section{Environment-societal system}

None of the reviewed programmes include an explicit focus or drive with an environmentsocietal perspective, while one programme includes an implied element by incorporating the requirements of the National Research Foundation (NRF) in the South African context (Geber 2009) as part of the individual development component of the programme.

\section{Recursiveness}

The fundamental notion to understanding the STF, is that each system is an open system and subject to multi-direction influence or interaction with each other (Patton and McMahon 2015). This is clearly depicted in all the reviewed articles as platforms were created for critical interaction through the above-mentioned coaching and mentoring methodologies, as well as the academic writing retreats.

\section{DISCUSSION}

The aim of this review was to identify and discuss the types of academic career development programmes that exist in the higher education sector that can inform a theoretical and evidencebased framework for the successful management of academic careers. An analysis of the abovementioned findings confirmed critical principles of career development theory in general; it revealed support for the fundamental arguments of scholars in the academic career development conversation; while further highlighting the opportunity and critical considerations during the development of career development programmes for academics.

In a study conducted by Pienaar and Bester $(2008,32)$, the researchers advocate the need for a comprehensive career management approach, by specifically encouraging universities to recognise the challenges of academics at all stages of their careers, and then to develop focused career management strategies that will assist them to deal with such challenges in a successful manner. Similarly, Callaghan $(2015,4)$ confirms the need for a bespoke approach that identifies the career challenges that need to be resolved at all the various levels of an academic career in order to support the academic career progression. A more recent study identifies the limited research that exists on a systematic career development approach for academics and that insufficient empirical studies of structured or formalised programmes have been captured (Zacher et al. 2019, 258). Moreover, the researchers advocate that there is a lack of attention regarding mid- and late-academic career development, which the outcome of the current review clearly confirms.

The review also reiterates that the individual is a fundamental construct of the career 
development process, as underpinned by the STF. While only two of the reviewed programmes were found to consider a formal individual needs assessment during the development phase of the programme (Benvenuti 2017; Kapp et al. 2011), another programme included an optional training module. This, in turn, allowed the individual needs of participants to be accommodated (Geber 2009). However, the needs of participants had to be considered as the remainder of the programmes organically unfolded (Ferguson and Wheat 2015; Abodunde 2018; Undiyaundeye and Basake 2017). In addition, the article by Benvenuti (2017) emphasises that the success of the programme relies on the careful design and planning of each writing retreat and this in turn, requires knowledge of the retreat participants and their needs in advance of the retreat. Developers of career management programmes for academics would therefore need to keep in mind that the individual needs of their target audience are essential for the career development process.

At the same time, while the reviewed programmes highlight individual needs as an important element, the predominant focus of the programmes are found to be constructed within the social system of the STF. Though individual autonomy could be implied through the level of influence participants had in choosing their mentor or coach (Geber 2009; Abodunde 2018; Undiyaundeye and Basake 2017), as well as a few workshops that were included as optional during a programme (Benvenuti 2017), the findings of the review indicate that limited empirical research is recorded that highlights the academics as active agents in the production of their careers. It is therefore clear that the theoretical and literature frameworks of the reviewed programmes hold a sound philosophical influence of social constructivism. According to Collin and Young (1986), social constructivism recognises the value of context and places a premium on understanding the processes of knowledge construction. Therefore, the review as underpinned by the STF, confirms the need for developers of academic career development programmes to consider the philosophical perspective of constructivism by understanding academic career development from an individual perspective.

The review asserts the role and mutual beneficial importance of academic career management practices for both the academic and the institution, through the strategic objectives of programmes that aim to increase the research productivity of academics and in turn, of the university (Geber 2009; Benvenuti 2017; Kapp et al. 2011). In addition, it is clear from this review that developing the academic writing skills through creating academic writing platforms and retreats is a central career management practice in the higher education sector. At the same time, the term academic career opens a diverse and complex world that defies easy definition or categorisation (Strike and Taylor 2009). Pithouse-Morgan et al. (2016) further argues that being an academic, what constitutes academic work and the meanings associated with 
becoming an academic are contested and constantly changing. This change in the academic role appears to be a dominant theme in academic career literature (Baruch 2013; Callaghan 2015; Pienaar and Bester 2008; Theron, Barkhuizen, and Du Plessis 2014). The review therefore confirms the need for academic career development programmes to consider and include a holistic approach to the role and requirements of the academic career.

Vondracek et al. (2014) posits that it is essential to think of career development as an integrated and dynamic process. Similarly, this review shows the inseparability of parts from the whole through the multi-directional influence and impact of the reviewed coaching, mentoring and writing retreat practices and programmes. At the same time, it is evident that findings of the review include limited explicit consideration for the higher education context in the broader environmental-societal system. According to Maguad (2017), the effectiveness of an improvement initiative should not be addressed in isolation, as the elements of the higher education system, like any other organisation, are interrelated and interdependent. This argument is preceded by a study conducted by Baruch and Peiperl (2000), which highlights the importance of managing careers in an organisation as an actual system, which requires key consideration for contextual factors, such as the organisation's stage of development, form and/or industry. Developers of academic career development programmes should therefore give considerable thought and understand that the challenges in the higher education system, and moreover, the context within which it operates is thus important to ensure the effective management of academic careers (Baruch and Peiperl 2000; Guravaiah 2017; Maguad 2017; Szelagowska-Rudzka 2017).

\section{LIMITATIONS}

Access to limited databases could have excluded peer reviewed articles and programmes from the respective review and could therefore be identified as a limitation.

\section{CONCLUSIONS}

It is evident from the review, that the career development practices in higher education focuses on the development and support of emerging academics, while highlighting the need to support academics in all phases of their careers as an ongoing development process. The practices aimed at early career academics include a dominant focus on coaching and mentoring, together with the development of academic writing skills and the creation of academic writing retreats and platforms. Furthermore, in line with the STF, the review highlights the need for developers of academic career development programmes to consider academic career development from an individual perspective and acknowledge the academic as an active agent in the career 
development process, while considering a more holistic and integrated view of the academic role within a contemporary higher education context.

\section{REFERENCES}

Abele, Andrea E. and Bettina S. Wiese. 2008. "The nomological network of self-management strategies and career success." Journal of Occupational and Organizational Psychology 81(4): 733-749. https://doi.org/10.1348/096317907X256726.

Abodunde, Sola, M. 2018. "Mentoring and Its Influence on Career Development of Academic Members of Selected Tertiary Institutions in Oyo State, Nigeria". Asian Research Journal of Arts \& Social Sciences 6(1): 1-9. https://doi.org/10.9734/ARJASS/2018/39815.

Baruch, Yehuda. 2006. "Career development in organizations and beyond: Balancing traditional and contemporary viewpoints." Human Resource Management Review 16(2): 125-138. https://doi.org/10.1016/j.hrmr.2006.03.002.

Baruch, Yehuda. 2013. "Careers in academe: The academic labour market as an eco-system." Career Development International 18(2): 196-210. https://doi.org/10.1108/CDI-09-2012-0092.

Baruch, Yehuda and Maury Peiperl. 2000. "Career management practices: An empirical survey and implications." Human Resource Management 39(4): 347-366. https://doi.org/10.1002/1099050X(200024)39:4<347::AID-HRM6>3.0.CO;2-C.

Benvenuti, S. 2017. "Pedagogy of peers: Cultivating writing retreats as communities of academic writing practice." South African Journal of Higher Education 31(2): 89-107. http://dx.doi.org/10.208535/31-2-1340.

Blustein, David L. 2014. “Implications for career theory.” In Women's Career Development Throughout the Lifespan, 235-246. Abingdon: Routledge.

Callaghan, Chris W. 2015. "Designation differences and academic career progression." Acta Commercii 15(1): 1-12. http://dx.doi. org/10.4102/ac.v15i1.267.

CHE see Council on Higher Education.

Clarke, Marilyn. 2013. "The organizational career: Not dead but in need of redefinition." The International Journal of Human Resource Management 24(4): 684-703. https://doi.org/ 10.1080/09585192.2012.697475.

Council on Higher Education. 2016. South African higher education reviewed: Two decades of democracy. Pretoria: CHE.

Collin, Audrey and Richard A. Young. 1986. "New directions for theories of career." Human Relations 39(9): 837-853. https://doi.org/10.1177/001872678603900904.

De Vos, Ans and Bart Cambré. 2017. "Career management in high-performing organizations: A settheoretic approach." Human Resource Management 56(3): 501-518. https://doi.org/ $10.1002 / \mathrm{hrm} .21786$.

De Vos, Ans, Inge De Clippeleer, and Thomas Dewilde. 2009. "Proactive career behaviours and career success during the early career." Journal of Occupational and Organizational Psychology 82(4): 761-777.

De Vos, Ans and Nicky Dries. 2013. "Applying a talent management lens to career management: The role of human capital composition and continuity." The International Journal of Human Resource Management 24(9): 1816-1831. https://doi.org/10.1080/09585192.2013.777537.

De Vos, Ans and Nele Soens. 2008. "Protean attitude and career success: The mediating role of selfmanagement." Journal of Vocational Behavior 73(3): 449-456. https://doi.org/10.1016/ j.jvb.2008.08.007.

Direnzo, Marco S., Jeffrey H. Greenhaus, and Christy H. Weer. 2015. "Relationship between protean career orientation and work-life balance: A resource perspective." Journal of Organizational 
Behavior 36(4): 538-560. https://doi.org/10.1002/job.1996.

Dries, Nicky, Frederik Van Acker, and Marijke Verbruggen. 2012. "How 'boundaryless' are the careers of high potentials, key experts and average performers?" Journal of Vocational Behavior 81(2): 271-279. https://doi.org/10.1016/j.jvb.2011.10.006.

Eby, Lillian T., Tammy D. Allen, and Andi Brinley. 2005. "A cross-level investigation of the relationship between career management practices and career-related attitudes." Group \& Organization Management 30(6): 565-596. https://doi.org/10.1177\%2F1059601104269118.

Eby, Lillian T., Marcus Butts, and Angie Lockwood. 2003. "Predictors of success in the era of the boundaryless career." Journal of Organizational Behavior: The International Journal of Industrial, Occupational and Organizational Psychology and Behavior 24(6): 689-708. https://doi.org/10.1002/job.214.

Fairchild, David G., Evan M. Benjamin, David R. Gifford, and Stephen J. Huot. 2004. "Physician leadership: Enhancing the career development of academic physician administrators and leaders." Academic Medicine 79(3): 214-218.

Ferguson, Hazel, and Katherine L. Wheat. 2015. "Early career academic mentoring using Twitter: The case of\# ECRchat." Journal of Higher Education Policy and Management 37(1): 3-13. https://doi.org/10.1080/1360080X.2014.991533.

Geber, Hilary. 2009. "Research success and structured support: developing early career academics in higher education." South African Journal of Higher Education 23(4): 674-689. https://hdl.handle.net/10520/EJC37555.

Greenhaus, Jeffrey H., Gerard A. Callanan, and Veronica M. Godshalk. 2010. Career management. Thousand Oaks, CA: Sage Publications.

Greenhaus, Jeffrey H., and Ellen Ernst Kossek. 2014. "The contemporary career: A work-home perspective." Annual Review of Organizational Psychology and Organizational Behavior 1(1): 361-388.

Guan, Yanjun, Wenxia Zhou, Lihui Ye, Peng Jiang, and Yixin Zhou. 2015. "Perceived organizational career management and career adaptability as predictors of success and turnover intention among Chinese employees." Journal of Vocational Behavior 88: 230-237. https://oi.org/10.1016/ j.jvb.2015.04.002.

Gubler, Martin, John Arnold, and Crispin Coombs. 2014. "Reassessing the protean career concept: Empirical findings, conceptual components, and measurement." Journal of Organizational Behavior 35(S1): S23-S40. https://doi.org/10.1002/job.1908.

Guravaiah, P. 2017. "A Review of Higher Education Issues, Challenges and Responses in India." International Journal of Research in Commerce \& Management 8(9): 49-53.

Isaacs, Serena Ann, Nicolette Vanessa Roman, Shazly Savahl, and Xin-Cheng Sui. 2018. "Using the RE-AIM framework to identify and describe best practice models in family-based intervention development: A systematic review." Child \& Family Social Work 23(1): 122-136. https://doi.org/10.1111/cfs.12380.

Kapp, C. A., R. M. Albertyn, and B. L. Frick. 2011. "Writing for publication: An intervention to overcome barriers to scholarly writing." South African Journal of Higher Education 25(4): 741759. https://hdl.handle.net/10520/EJC37708.

King, Zella. 2004. "Career self-management: Its nature, causes and consequences." Journal of Vocational Behavior 65(1): 112-133. https://doi.org/10.1016/S0001-8791(03)00052-6.

Lee, Colin I. S. G., Will Felps, and Yehuda Baruch. 2014. "Toward a taxonomy of career studies through bibliometric visualization." Journal of Vocational Behavior 85(3): 339-351. https://doi.org/10.1016/j.jvb.2014.08.008.

Lips-Wiersma, Marjolein, and Douglas T. Hall. 2007. "Organizational career development is not dead: A case study on managing the new career during organizational change." Journal of Organizational Behavior: The International Journal of Industrial, Occupational and Organizational Psychology and Behavior 28(6): 771-792. https://doi.org/10.1002/job.446. 
Maguad, Ben A. 2017. "Managing for quality in higher education: A biblical perspective." In 40th International Faith and Learning Seminar held at Asia-Pacific International University Muak Lek, Saraburi, Thailand. http://digitalcommons.andrews.edu/cgi/viewcontent.cgi?article $=1062 \&$ context=autlc.

McMahon, Mary, and Wendy Patton. 2018. "Systemic thinking in career development theory: Contributions of the Systems Theory Framework." British Journal of Guidance \& Counselling 46(2): 229-240.

Moher, David, Larissa Shamseer, Mike Clarke, Davina Ghersi, Alessandro Liberati, Mark Petticrew, Paul Shekelle, and Lesley A. Stewart. 2015. "Preferred reporting items for systematic review and meta-analysis protocols (PRISMA-P) 2015 statement.” Systematic reviews 4(1): 1.

Parsons, Frank. 1909. Choosing a vocation. Boston: Houghton Mifflin.

Patton, Wendy and Mary McMahon. 1999. Career development and systems theory: A new relationship. Pacific Grove, CA: Thomson Brooks/Cole Publishing Company.

Patton, Wendy and Mary McMahon. 2014. Career development and systems theory: Connecting theory and practice. Rotterdam, The Netherlands: Sense.

Patton, Wendy, and Mary McMahon. 2015. "The systems theory framework of career development: 20 years of contribution to theory and practice." Australian Journal of Career Development 24(3): 141-147. https://doi.org/10.1177\%2F1038416215579944.

Pienaar, Cobus, and Coen L. Bester. 2008. "The retention of academics in the early career phase: Empirical research." SA Journal of Human Resource Management 6(2): 32-41. https://hdl.handle.net/10520/EJC95871.

Pithouse-Morgan, K., I. Naicker, D. Pillay, L. Masinga, and T. Hlao. 2016. “'Sink or swim?': Learning from stories of becoming academics within a transforming university terrain." South African Journal of Higher Education 30(1): 224-244. DOI: https://doi.org/10.20853/30-1-561

Segers, Jesse, and Ilke Inceoglu. 2012. "Exploring supportive and developmental career management through business strategies and coaching." Human Resource Management 51(1): 99-120.

Schardt, Connie, Martha B. Adams, Thomas Owens, Sheri Keitz, and Paul Fontelo. 2007. "Utilization of the PICO framework to improve searching PubMed for clinical questions." BMC medical informatics and decision making 7(1): 16.

Strike, Tony, and John Taylor. 2009. "The career perceptions of academic staff and human resource discourses in English higher education." Higher Education Quarterly 63(2): 177-195.

Super, Donald E. 1990. "A Life-Span, Life-Space Approach to Career Development. Inside D. Brown, L. Brooks, \& Associates (Ed.), Career Choice and Development (ss. 197-261).” San Francisco, CA: Jossey-Bass.

Strauss, Karoline, Mark A. Griffin, and Sharon K. Parker. 2012. "Future work selves: How salient hoped-for identities motivate proactive career behaviors." Journal of Applied Psychology 97(3): 580-598.

Szelągowska-Rudzka, Katarzyna. 2017. "Human Resources Management in Higher Education Institutions in Poland." Management 22(1): 208-225. DOI: 10.2478/manment-2018-0015

Theron, Marguerite, Nicolene Barkhuizen, and Yvonne Du Plessis. 2014. "Managing the academic talent void: Investigating factors in academic turnover and retention in South Africa." SA Journal of Industrial Psychology 40(1): 01-14. $\quad<\mathrm{http}: / / w w w . s c i e l o . o r g . z a / s c i e l o . p h p ? s c r i p t=s c i$ arttext\&pid=S2071-07632014000100009\&lng=en\&nrm=iso $>$. access on 07 Mar. 2020.

Undiyaundeye, Florence A. and Julius A. Basake. 2017. "Mentoring and career development of academics in colleges of education in Cross River State Nigeria." European Journal of Multidisciplinary Studies 2(4): 98-104. https://dx.doi.org/10.26417/ejms.v4i4.p98-104.

Vondracek, Fred W., Donald H. Ford, and Erik J. Porfeli. 2014. "A living systems theory of vocational behavior and development." In A living systems theory of vocational behavior and development, 55-80. Rotterdam: SensePublishers. 
Young, Richard A. and Natalee E. Popadiuk. 2012. "Social constructionist theories in vocational psychology." In Social constructionism in vocational psychology and career development, 9-28. Brill Sense.

Zacher, Hannes, Cort W. Rudolph, Tara Todorovic, and Daniel Ammann. 2019. "Academic career development: A review and research agenda." Journal of Vocational Behavior 110: 357-373. https://doi.org/10.1016/j.jvb.2018.08.006 